POLITYKA ENERGETYCZNA - ENERGY POLICY JOURNAL

$2019 \star$ Volume $22 \star$ Issue $4 \star 115-128$

DOI: $10.33223 / \mathrm{epj} / 112760$

Adam SzURLEJ $^{1}$, Mariusz ŁACIAK $^{2}$, Oleksandr BoIKO ${ }^{3}$, Andrzej OliJnYK ${ }^{4}$

\title{
The natural gas sector in Ukraine - opportunities and barriers to growth
}

ABSTRACT: The paper analyzed the natural gas sector in Ukraine for the period 2000 to 2018. This sector was affected by external factors, such as the crisis which began in late 2008/2009, as well as internal factors, including the situation in Ukraine after 2013 (the Annexation of Crimea). A comparative analysis was also conducted of the natural gas sector in European Union countries and Ukraine compared the specificity of natural gas consumption in 2018. The analysis (I) examined the demand for natural gas in Ukraine between 2000 and 2018; (II) described changes in sources to cover Ukraine's gas needs with a particular emphasis on its own production; (III) pointed to the fundamental changes that have occurred in the natural gas supply routes to the Ukrainian sector in recent years; (IV) stressed the growing role of own production in balancing Ukraine's gas needs; (V) described the role of Ukraine as a transit country for Russian gas to be delivered to EU countries (in recent

$\triangle$ Corresponding Author: Adam Szurlej; e-mail: szua@agh.edu.pl

1 Department of Natural Gas Engineering, Faculty of Drilling, Oil \& Gas, AGH University of Science and Technology, Kraków, Poland; ORCID iD: 0000-0003-3872-9019; e-mail: szua@agh.edu.pl

2 Department of Natural Gas Engineering, Faculty of Drilling, Oil \& Gas, AGH University of Science and Technology, Kraków, Poland; ORCID iD: 0000-0002-7450-7045; e-mail: laciak@agh.edu.pl

3 Department of Natural Gas Engineering, Faculty of Drilling, Oil \& Gas, AGH University of Science and Technology, Kraków, Poland; ORCID iD: 0000-0001-6355-5562; e-mail: bojkooles@gmail.com

4 Department of Natural Gas Engineering, Faculty of Drilling, Oil \& Gas, AGH University of Science and Technology, Kraków, Poland; ORCID iD: 0000-0001-5201-8809; e-mail: aoliinyk@agh.edu.pl

2019. The Author(s). This is an open-access article distributed under the terms of the Creative Commons Attribution-ShareAlike International License (CC BY-SA 4.0, http://creativecommons.org/licenses/by-sa/4.0/), which permits use, distribution, and reproduction in any medium, provided that the Article is properly cited. 
years, the volume of natural gas transmitted via the Ukrainian transmission system has been around $90 \mathrm{bcm}$ annually); and (VI) looked at the structure of natural gas consumption in the Ukrainian gas sector and how it has changed in recent years. Unlike EU countries, the growing role of own production in balancing Ukraine's natural gas needs was emphasized, which is consistent with the strategy of the Ukrainian government. Also, attention was drawn to the threats that may significantly reduce the role of Ukraine as an important transit country. The paper also puts forward the most important parameters concerning the underground natural gas storage facilities in Ukraine which is one of the largest in Europe.

KEYWORDS: natural gas sector, natural gas, energy security, energy policy

\section{Introduction}

Taking the consumption of natural gas into account, it usually increases if the economy of the country develops. But there are some unpredictable factors that depend on geopolitical conditions and dynamic developments in the financial situation. Natural gas plays a significant role in the structure of primary energy consumption in Ukraine. Due to the volume of its consumption, natural gas is the first largest energy carrier after oil and in 2018 accounted for $31 \%$ (BP 2019) of primary energy consumption. In the early years of the 21 st century, the share of natural gas was higher - about 45\%. For comparison, in the case of the European Union (EU), natural gas is on the second energy carrier in the energy balance behind oil, but its share is lower and in 2018 amounted to 23.6\% (BP 2019). Ukraine and the EU's energy security, as regards natural gas, depends, among others, on the priorities of the energy policy and the strategy for the diversification of natural gas supply sources. In 2018, 77.9\% (BP 2019) of natural gas was imported to EU countries. At the same time, approximately $13 \%$ of the total LNG imports and $87 \%$ of natural gas were delivered via pipeline systems (BP 2019). In the case of Ukraine, imports accounted for $44.08 \%$ of natural gas consumption. Russia and Norway were among the largest exporters of natural gas to EU countries. Until 2015 Ukraine had imported most of its natural gas from Russia; however, after 2015, import routes changed significantly and natural gas started being imported from EU countries. In August, the Ukrainian side held talks with Moldova in order to prepare a new gas supply route from Romania in the amount of 1.5 billion cubic meters (bcm) of gas per year. When analyzing natural gas supply routes, it is worth noting that although Ukraine has not been importing natural gas directly from Russia for several years, the transit of Russian natural gas to European countries is still taking place through its territory, and the volume of transit amounts to approximately $90 \mathrm{bcm}$ per year (Gas transit), which accounts for $44.7 \%$ of total natural gas imports from Russia. 


\section{Analysis of natural gas production and consumption in Ukraine, 2000-2018}

A comparison of trends in natural gas production in Ukraine and the EU shows some differences. Although at the beginning of the 21 st century the volume of natural gas production in the EU stood at $245 \mathrm{bcm}$, which accounted for a $53 \%$ share in covering natural gas needs, in recent years natural gas production has been systematically decreasing and has reached $109.2 \mathrm{bcm}$, i.e. it has covered only $23.8 \%$ of the demand for natural gas in EU countries. As for Ukraine, Table 1 and Figure 1 show the dynamics of its natural gas production and consumption for the period 2000 to 2018.

TABLE 1. Natural gas production and consumption in Ukraine, 2000-2018 [bcm]

TABELA 1. Wydobycie i zużycie gazu ziemnego w Ukrainie w latach 2000-2018 [ $\mathrm{mld} \mathrm{m}^{3}$ ]

\begin{tabular}{|c|c|c|c|c|c|c|c|c|c|c|c|c|c|c|c|c|c|c|c|}
\hline Year & $\underset{ి}{8}$ & 홍 & ণి & હ̊ণ & ঠ্ণ & 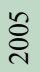 & ঠి & 옹 & $\stackrel{\infty}{\stackrel{\overbrace{}}{8}}$ & ஓి & $\stackrel{0}{\frac{0}{\circ}}$ & స్త & $\stackrel{ }{\stackrel{ }{2}}$ & $\stackrel{m}{\stackrel{n}{\sim}}$ & $\underset{\text { ণ }}{\stackrel{ \pm}{\circ}}$ & $\stackrel{n}{\tilde{0}}$ & $\stackrel{0}{\stackrel{0}{0}}$ & 공 & $\frac{\infty}{\sigma}$ \\
\hline $\begin{array}{c}\text { Natural gas } \\
\text { production } \\
{[\mathrm{bcm} / \mathrm{y}]}\end{array}$ & $\begin{array}{l}\infty \\
\infty \\
\stackrel{\infty}{n}\end{array}$ & $\begin{array}{l}\stackrel{0}{0} \\
\stackrel{0}{0}\end{array}$ & \begin{tabular}{l}
$\infty$ \\
\multirow{\sigma}{5}{} \\
$I$
\end{tabular} & 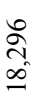 & $\begin{array}{l}0 \\
\stackrel{0}{0} \\
\stackrel{2}{2}\end{array}$ & $\begin{array}{l}\tilde{\sigma} \\
\Omega\end{array}$ & 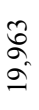 & $\begin{array}{l}\tilde{\sigma} \\
\hat{\sigma}\end{array}$ & 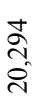 & ஸे & 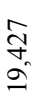 & \begin{tabular}{l}
$\forall$ \\
\multirow{2}{*}{} \\
$\sigma$
\end{tabular} & 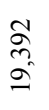 & $\frac{\infty}{\stackrel{n}{n}}$ & 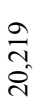 & $\begin{array}{l}m \\
\infty \\
\infty \\
\infty\end{array}$ & 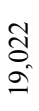 & $\begin{array}{l}\exists \\
\text { Jू } \\
\text { a }\end{array}$ & $\begin{array}{l}n \\
\infty \\
\infty \\
2\end{array}$ \\
\hline $\begin{array}{c}\text { Natural gas } \\
\text { consumption } \\
{[\mathrm{bcm} / \mathrm{y}]}\end{array}$ & $\begin{array}{l}\stackrel{2}{+} \\
\frac{\pi}{\pi}\end{array}$ & $\frac{\widehat{a}}{\widehat{\sigma}}$ & 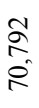 & 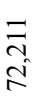 & $\frac{\text { go }}{\mathbb{i}}$ & $\begin{array}{l}= \\
\text { Nิ } \\
\text { N }\end{array}$ & 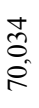 & 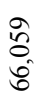 & 犬ิ & $\begin{array}{l}\stackrel{8}{\circ} \\
\text { + }\end{array}$ & 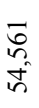 & $\frac{\hat{n}}{\overbrace{}^{\circ}}$ & $\stackrel{\hat{\infty}}{\infty}$ & 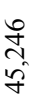 & $\begin{array}{c}\substack{\infty \\
+\\
\infty} \\
\text { n }\end{array}$ & $\begin{array}{l}\stackrel{2}{0} \\
\text { on }\end{array}$ & $\begin{array}{l}\hat{2} \\
\text { ñ } \\
\text { ñ }\end{array}$ & $\frac{\pi}{\stackrel{2}{N}}$ & $\begin{array}{l}\text { ह } \\
\text { กิ }\end{array}$ \\
\hline
\end{tabular}

Source: Author's own study based on (BP 2018; BP 2019; Naftogaz01).

As Figure 1 shows, the production of natural gas in Ukraine increased from 2000 to 2009 and this increase accounted for about 29\%. However, after 2009 there was a decline in natural gas production by about $4.5 \%$ and until 2012 the production remained almost at the same level. In 2013 the production increased again, and then decreased in 2015 by around $6.8 \%$. Between 2016 and 2018, natural gas production in Ukraine increased. For the last year alone, production has increased by about $2.4 \%$ and amounted to nearly $20 \mathrm{bcm}$. It is worth noting that in the mid-1970s, the Ukrainian SSR was a significant producer of natural gas with an output of $68 \mathrm{bcm} / \mathrm{y}$ (including about $12 \mathrm{bcm}$ of natural gas produced in western Ukraine), which accounted for one-fourth of the volume of natural gas produced in the USSR. In subsequent years, however, the volume of production began to fall steeply, reaching 42 bcm in the mid-1980s (Konończuk 2018.).

The largest company engaged in the production of natural gas in Ukraine is UkrGasVydobuvannya. In 2018 , the company produced $73.8 \%$ of natural gas in Ukraine. Ukrnafta ranked second with a $5.2 \%$ production, and Chornomornaftogaz ranked third with a $0.05 \%$ production. State-owned companies produced $79.05 \%$ of the total natural gas volume (Naftogaz02). In addition to state-owned companies, there are also private companies in Ukraine producing natural 


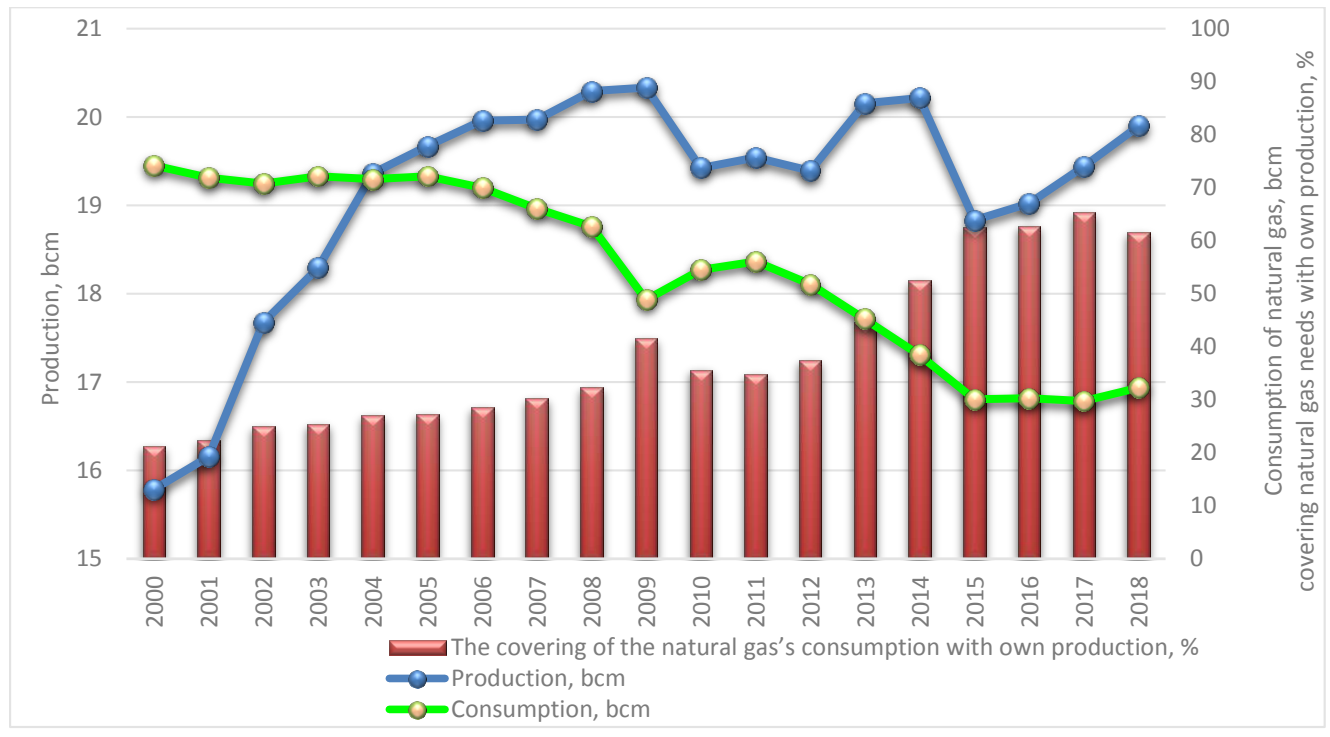

Fig. 1. Ukraine's natural gas production and consumption [bcm] and its own production share in covering natural gas needs [\%], 2000-2018

Source: Author's own study based on (BP 2018; BP 2019; Naftogaz 01)

Rys. 1. Wydobycie i zużycie gazu ziemnego [mld $\mathrm{m}^{3}$ ] oraz pokrycie zużycia gazu ziemnego własnym wydobyciem [\%] w Ukrainie w latach 2000-2018

gas, and their number is estimated to be more than 100 (Permission List 2015). In 2018 natural gas produced by private companies amounted to $20.95 \%$ of the total natural gas output. The largest private companies producing natural gas in Ukraine include DTEK Naftogaz, Burisma Holdings, Ukrnaftoburinia, JKX Oil\&Gas, Geo Alliance and Smart Energy (Martynenko 2018).

When analyzing the importance of natural gas production in Ukraine, it is worth mentioning that the Kiev government's strategy regarding natural gas assumes its increase in production within the next few years and that Ukraine will ultimately become a natural gas exporter. That is why the Ukrainian government has reduced tax rates for the natural gas sector, deregulated the legislation and approved a proposal of loan for UkrGasVydobuvannya for the development of natural gas production in Ukraine. These funds will be used to purchase equipment and upgrade infrastructure in order to cooperate more effectively with the American companies DeGolyer and MacNaughton Corp, which both, in February 2019, won the tender to evaluate the potential of new hydrocarbon fields in Ukraine (Hydrocarbon exploration).

The analysis of natural gas consumption in Ukraine shows a systematic decrease which between 2000 and 2018 amounted to almost 56.5\% and reached $32.3 \mathrm{bcm}$ (2018). The biggest drop was recorded in 2009 caused by the global crisis. In 2015 the consumption stabilized at approximately $30 \mathrm{bcm}$, and by 2017 it had remained almost at the same level, while in 2018 a slight increase of about $2.4 \%$ was observed in natural gas consumption. A closer examination of the indicators of Ukraine's own production share in covering natural gas needs shows positive 
changes as well. Compared to 2000, in 2018 the share of its own production in covering natural gas needs increased by about $189.5 \%$, and in 2018 this indicator was almost $62 \%$, which translates into reduced threats to the country's energy security, which could result from disruptions in the supply of natural gas imports.

When comparing Ukraine with EU countries in terms of volumes of natural gas consumption, it can be observed that the largest consumers of natural gas in Europe, as shown in Figure 2, were Germany (about $89 \mathrm{bcm}$ ), the UK (about $79 \mathrm{bcm}$ ) and Italy (about $70 \mathrm{bcm}$ ). In 2018, Ukraine was ranked seventh in Europe in terms of natural gas consumption volumes.

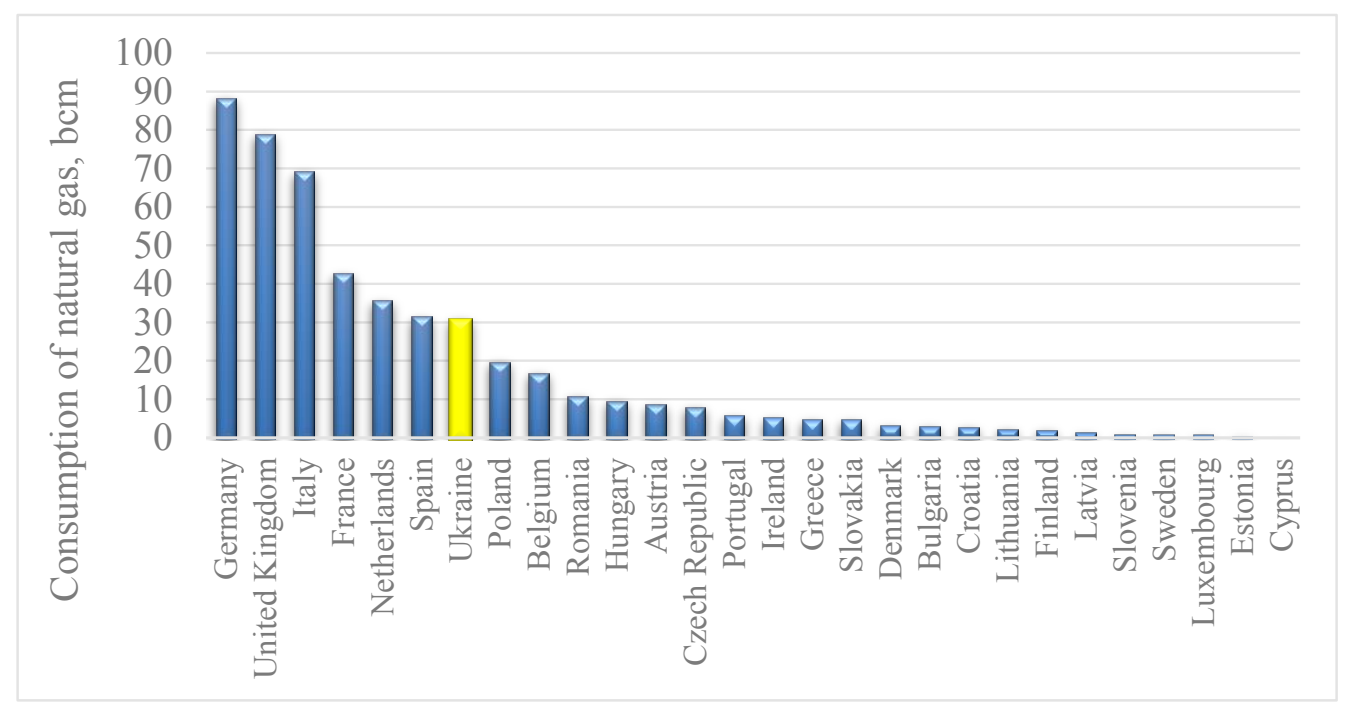

Fig. 2. Comparison of natural gas consumption in Ukraine and EU countries, 2018 [bcm] Source: Author's own study based on (BP 2019)

Rys. 2. Porównanie zużycia gazu ziemnego w Ukrainie i krajach Unii Europejskiej w 2018 r. [mld $\mathrm{m}^{3}$ ]

If one takes the consumption of natural gas per capita among the EU countries and Ukraine into account, this comparison will bring Ukraine to $13^{\text {th }}$ place in 2018 (729.42 cubic meters of gas per capita) (BP 2019; List of population). The largest specific natural gas consumption was in the Netherlands (2,081 cubic meters), Belgium (1,458.34 cubic meters) and Luxembourg ( $1,312.58$ cubic meters).

Figure 3 shows changes in the structure of natural gas consumption in 2013 and 2018. The biggest changes can be seen in the sectors related to the use of natural gas for operating needs as well as in the sector of natural gas consumption for industrial sector (consumption declined by about $11 \%$ in 2018 compared to 2013). The consumption of natural gas by households was similar and the use of natural gas for heat production increased by $2 \%$. There were unauthorized offtake, unrecorded volumes and balancing in 2018 as well, which accounted for approximately $4 \%$. 

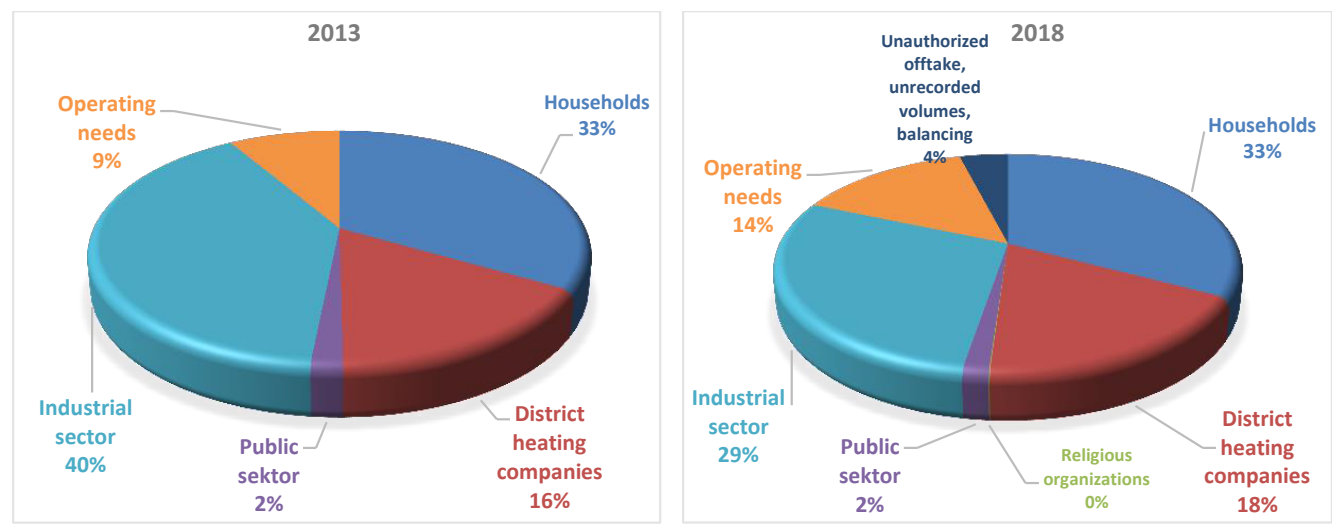

Fig. 3. Structure of natural gas consumption in Ukraine [\%]

Source: Author's own study based on (Naftogaz03; Naftogaz04)

Rys. 3. Struktura zużycia gazu ziemnego w Ukrainie [\%]

\section{Analysis of natural gas transit through Ukraine and its imports}

Important natural gas pipelines run through the territory of Ukraine, which supply natural gas from Russia to European countries. The total length of the Ukrainian transmission pipeline system is nearly $37,000 \mathrm{~km}$, the total entry capacity of the natural gas pipeline system is about $288 \mathrm{bcm}$ annually (in the northern and eastern part of the country), and the exit capacity is about 142-178 bcm (southern and western part) (Ruszel 2014). Figure 4 shows that the sharpest drops observed in transit - by about $20.6 \%$ and $19.7 \%$ - took place in 2009 and 2012 respectively, and then by about 33.8\% in 2014 (when the situation in Ukraine changed in 2013). But after 2014 the transit of natural gas through Ukraine increased and this increase remained at about $46.1 \%$ in 2018. The overall decrease in natural gas transit through Ukraine in 2018 was approximately $20.6 \%$ compared to 2000 .

To meet its own demand, Ukraine has been importing natural gas from other European countries. However, the imports of natural gas to Ukraine have been declining in recent years. Between 2000 and 2018, its natural gas imports decreased by approximately $82.1 \%$ and in 2018 amounted to $10.6 \mathrm{bcm}$. Previously, most imports of natural gas to Ukraine originated from Russia, but since 2015 there has been a fundamental change of direction and Ukraine continues to import natural gas from EU countries (as shown in Figs. 5 and 6), including Poland.

Ukraine's European routes for importing natural gas include Poland, Slovakia and Hungary. In 2018 Ukraine imported the largest volume of European natural gas from Slovakia - almost $58 \%$; Poland and Hungary displayed almost 11 and 31\% respectively. Compared to the previous 


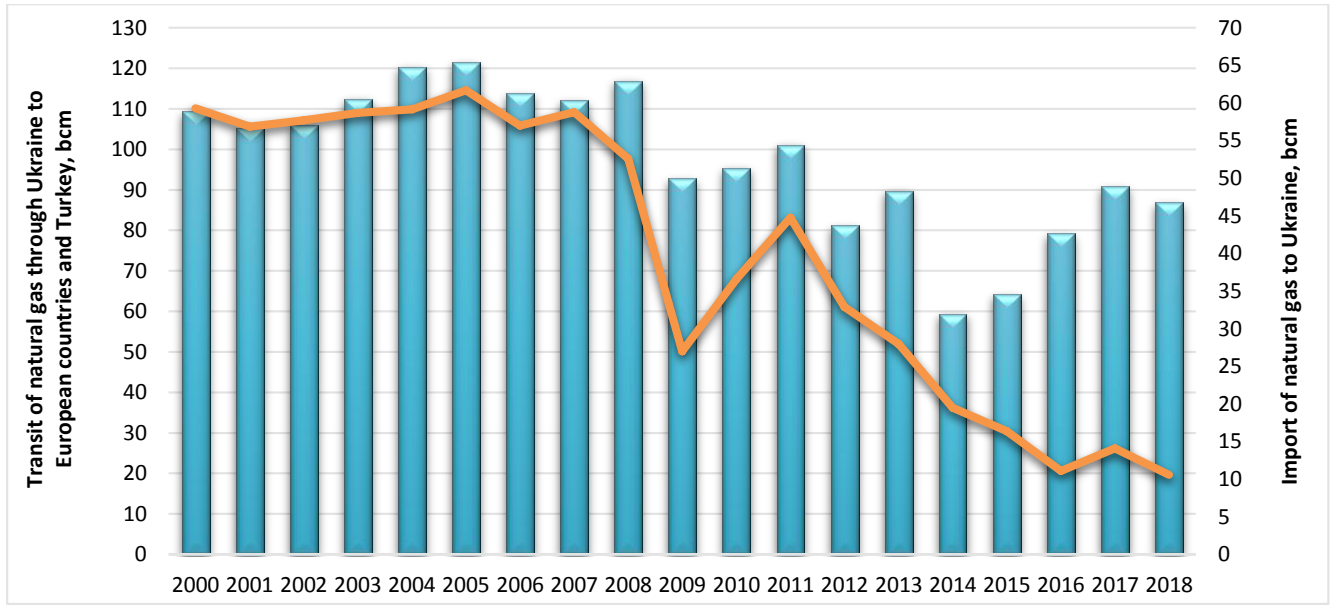

Fig. 4. Natural gas transit through Ukraine and natural gas imports to Ukraine, 2000-2018 [bcm] Source: Author's own study based on (Gas transit; Naftogaz05; Naftogaz06)

Rys. 4. Tranzyt gazu ziemnego przez Ukrainę i import gazu ziemnego do Ukrainy w latach 2000-2018 [mld $\mathrm{m}^{3}$ ]

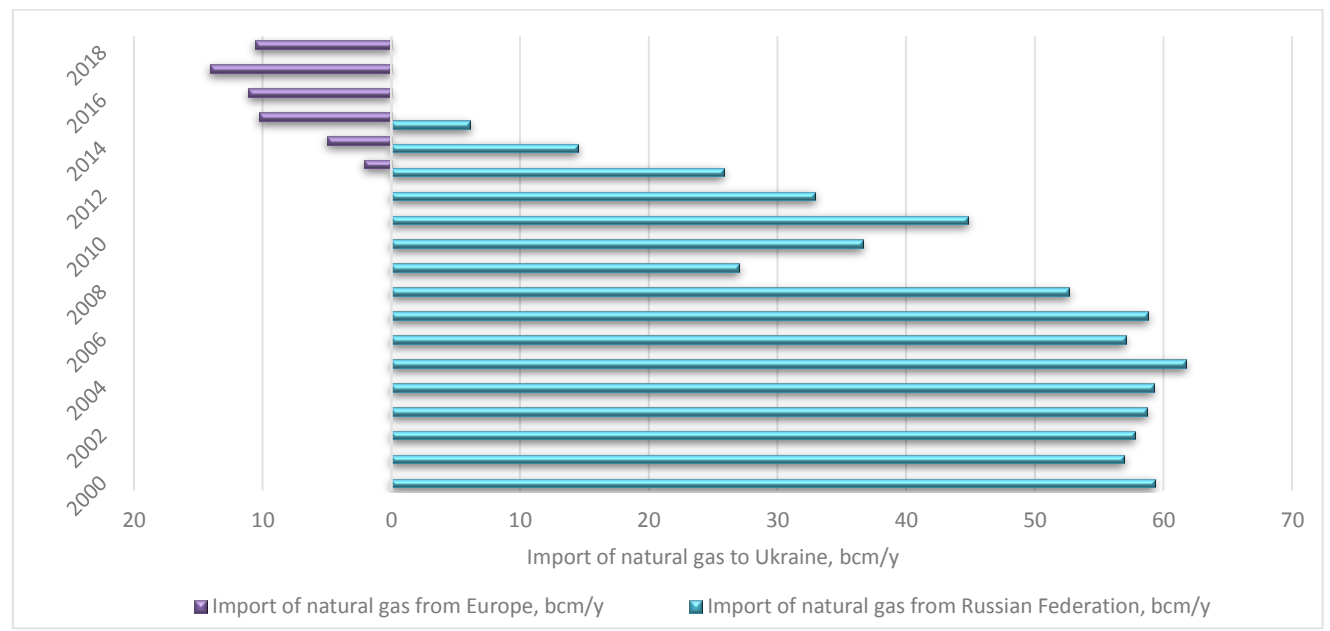

Fig. 5. Natural gas imports to Ukraine, 2000-2018 [bcm] Source: Author's own study based on (Naftogaz01; Naftogaz07)

Rys. 5. Import gazu ziemnego do Ukrainy w latach 2000-2018 [mld $\mathrm{m}^{3}$ ]

year, in 2018 natural gas imports from Slovakia fell by $34.4 \%$, while they increased by $24 \%$ in Hungary and decreased by $8.4 \%$ in Poland. Compared to 2017, in 2018 natural gas imports from Europe dropped by approximately $24.8 \%$.

The transit of natural gas plays a significant role in Ukraine. In 2017 alone, revenues from natural gas transit amounted to some USD 3 billion (bn). This sum was convergent 


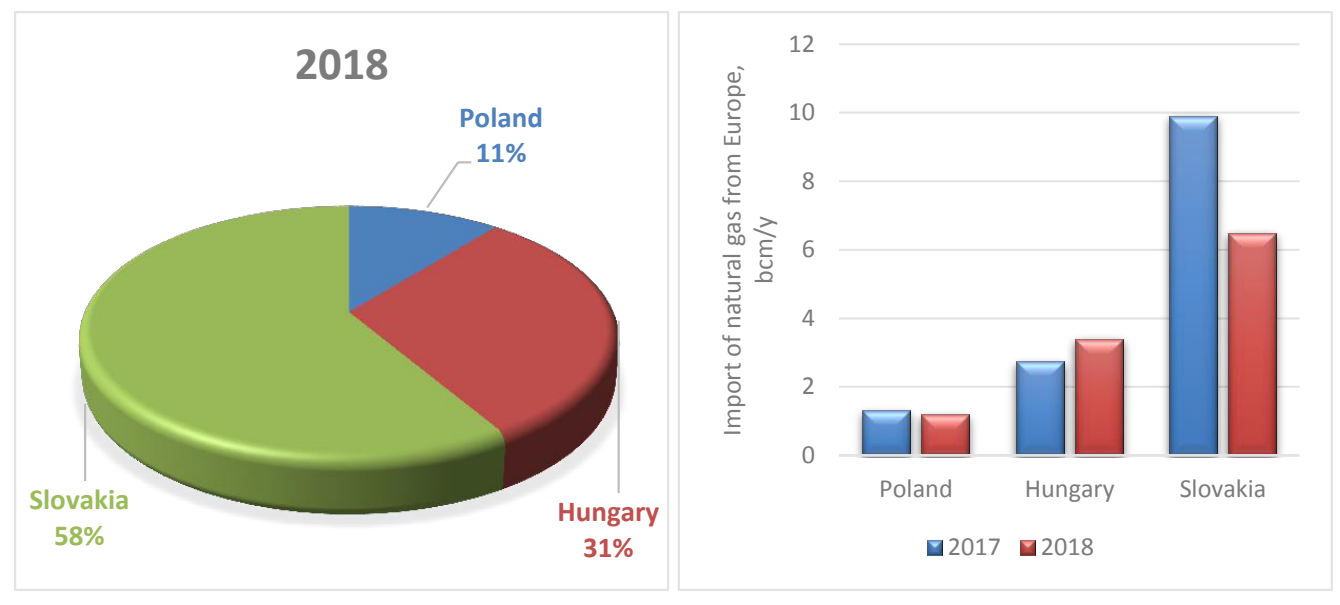

Fig. 6. Ukraine's natural gas imports from EU countries [\%] Source: Author's own study based on (Naftogaz08)

Rys. 6. Import gazu ziemnego do Ukrainy z krajów UE [\%]

with the expenditure on natural gas imports (USD 3.2bn) (Kardaś et al. 2019). In 2018, though, Ukraine's income from the transit of Russian natural gas exceeded its expenditure on natural gas imports and was higher by almost USD 0.5bn (Transit revenues). By doing so, Ukraine's main strategic goal is still to maintain the status of a transit country. It should be emphasized that in order for Ukraine to maintain the profit from natural gas transit, the country must send through its territory no less than $40 \mathrm{bcm}$ of natural gas per year. It seems that at present a serious threat to the development of the Ukrainian strategy may be the implementation of Russia's strategic energy policy goals, which differ from Ukraine's strategic goals. It is estimated that after the completion of important Russian projects Nord Stream 2 and TurkStream, after 2021, the total transit capacity of these natural gas pipelines will amount to approximately $86.5 \mathrm{bcm}$ per year. If, at the same time, it is assumed that there will be a steep fall in natural gas consumption in Europe, Ukraine may lose its status as a transit country for Russian natural gas already after 2021. It is worth mentioning here that EU representatives are interested in maintaining the transit of natural gas through Ukraine (Kardaś et al. 2019).

Figure 7 shows the natural gas exports via pipelines from Russia to European countries between 2000 and 2018. The volume of natural gas exports from Russia decreased significantly after the global crisis in 2009. Meanwhile, between 2014 and 2018, the volumes of natural gas supplies from Russia to European countries via pipelines were steadily increasing - in 2018 there was a $18.2 \%$ growth compared to 2014 .

A comparison of the volume of natural gas supplies from Russia using natural gas pipelines for transit through Ukraine shows that transit of natural gas through Ukraine accounts for $44.7 \%$ of the supplies of Russian natural gas to European countries. 


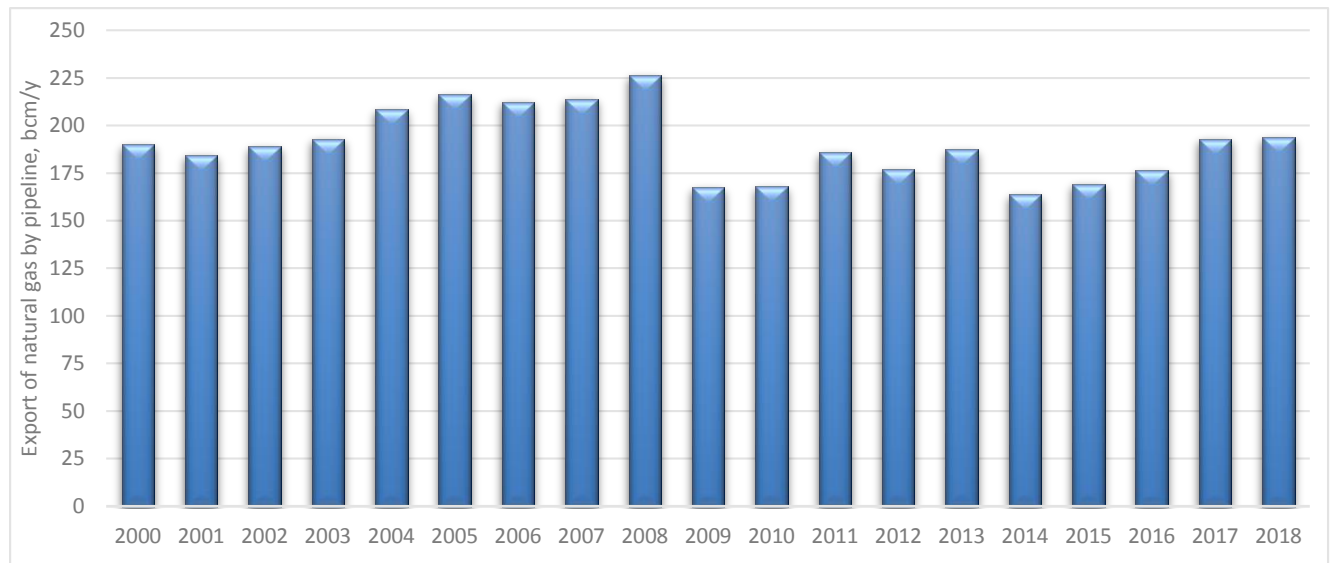

Fig. 7. Natural gas exports by pipelines from Russian Federation to European countries, 2000-2018 [bcm] Source: Author's own study based on (BP 2019)

Rys. 7. Eksport gazu ziemnego gazociągami z Rosji do krajów Europejskich w latach 2000-2018 [mld m3]

The main routes for the export of natural gas via pipelines from Russia to European countries are the Baltic Sea (Nord Stream), Belarus and Poland (Yamal-Europe), Ukraine and the Black Sea, and Turkey (Fig. 8). The Nord Stream 1 project (two pipeline strings) with a capacity of approximately $55 \mathrm{bcm}$ of natural gas per year (Nord Stream) was completed between 2010 and

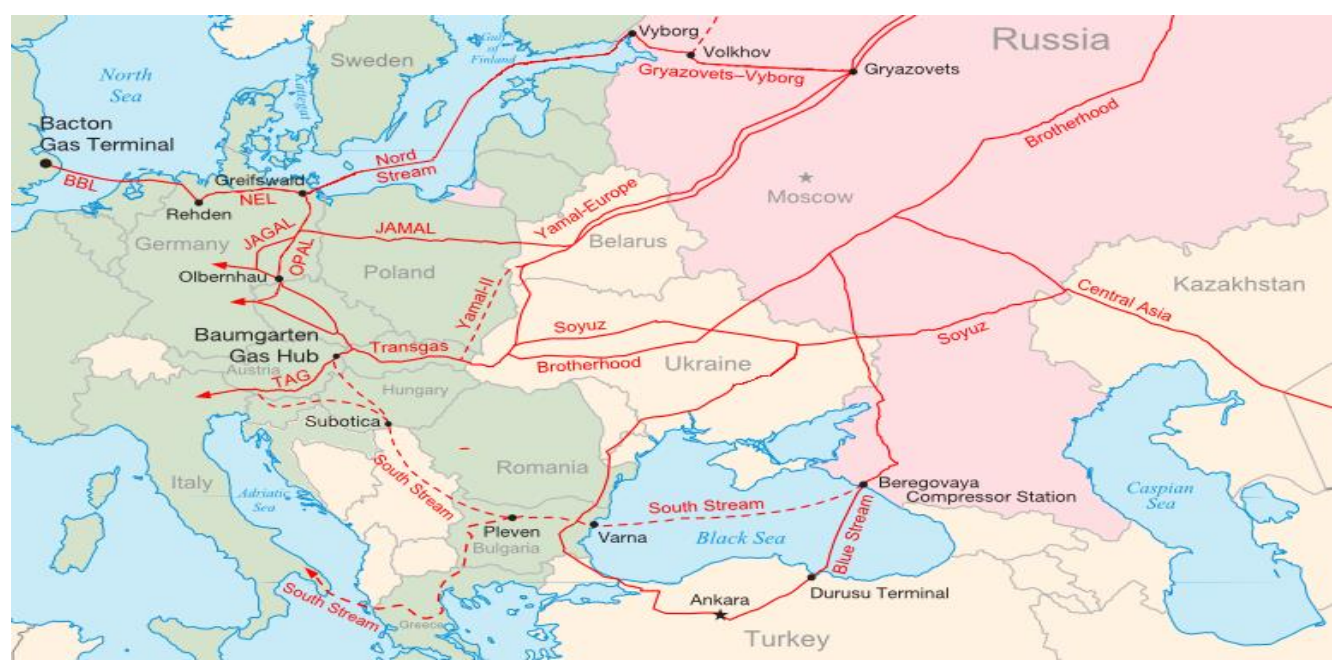

Fig. 8. Gas pipelines supplying natural gas from Russia and eastern countries to Europe Source: based on (Russian gas pipeline)

Rys. 8. Sieć gazociągów dostarczających gaz ziemny w kierunku z Rosji i krajów wschodnich do Europy 
2012. The Nord Stream 2 project (two additional pipeline strings) is currently under construction with a capacity of approximately $55 \mathrm{bcm}$ of natural gas per year (Nord Stream 2 is planned to be completed in 2019).

Natural gas is transmitted through Belarus and Poland via the Yamal-Europe natural gas pipeline which has a capacity of about $33 \mathrm{bcm}$ of natural gas per year (Gas pipelines bypassing Ukraine). The route of Russian natural gas supplies through Ukraine is currently the largest - the total capacity of natural gas pipelines amounts to some $145.8 \mathrm{bcm} / \mathrm{y}$ (Ukrtransgaz). Natural gas is exported from Russia through the Black Sea and Turkey via the Blue Stream pipeline which has a capacity of $16 \mathrm{bcm}$ of natural gas per year (Blue Stream). To sum up, the technical capacity to transport Russian gas via pipelines to European countries is approximately $250 \mathrm{bcm} / \mathrm{y}$.

\section{Underground Gas Storage facilities in Ukraine}

When analyzing the chances of Ukraine's natural gas sector, it is worth highlighting a well -developed network of underground natural gas storage facilities (UGSs). This is important in the context of ensuring the country's energy security. Ukraine has twelve UGSs, ten of which are located in former natural gas fields and two of which are in waterlogged structures (Ukrtransgaz).

One of the largest natural gas storage facilities in Ukraine is the Bilche-Volycko-Ugerskoe storage facility. Its capacity is about $17.64 \mathrm{bcm}$, and its daily designed offtake capacity is 160 million cubic meters ( $\mathrm{mcm}$ ). Another UGS is Bohorodchany facility - its capacity is about $2.3 \mathrm{bcm}$ and its daily designed offtake capacity is $46 \mathrm{mcm}$. The Dashavske UGS ranks third with its capacity of approximately $2.15 \mathrm{bcm}$ and a daily offtake of $25 \mathrm{mcm}$.

The total working UGS capacity is approximately $31 \mathrm{bcm}$. Thus, in 2018 the UGS capacity was about $4 \%$ lower than the annual consumption of natural gas in Ukraine. Only a few EU countries can boast such a ratio of consumption volume to UGS capacity. The total UGS capacity in EU countries stands at about $108 \mathrm{bcm}$ (Kaliski et al. 2015). The EU countries with the highest UGS capacity are Germany (approx. $21.9 \mathrm{bcm})$, Italy $(16.5 \mathrm{bcm})$ and France $(11.9 \mathrm{bcm})($ Kwiatkowicz and Szczerbowski 2015).

The main objectives of the Ukrainian UGSs include (i) levelling out the imbalance in natural gas consumption and (ii) balancing the supply of natural gas for Ukraine's own needs as well as (iii) playing an important role in maintaining the stability of natural gas transit to European countries. One of the functions of underground natural gas storage is also to maintain a supply of natural gas sufficient to cover Ukraine's own needs in situations where short-term interruptions in the supply of imported natural gas may occur or to ensure supply in the event of a breakdown. The location of UGS facilities in the transmission system allows for easy control to balance natural gas supplies. 


\section{Conclusion}

In recent years, most of the EU countries have seen a decline in natural gas production. Taking into account natural gas resources in Ukraine, which are among the largest in Europe (without taking into account Russia), it is expected that in the future - in line with the government's strategy - the upward trend in production will be maintained, which will translate into increased energy security. Although the Ukrainian natural gas reserves are large enough, the vast majority of fields are currently in the final stages of development. In order to actively support and develop natural gas production, the industry requires significant investments, which in the future can yield positive results.

In recent years (2000-2018), the consumption of natural gas in Ukraine has fallen by $56.5 \%$. On the other hand, the share of its own natural gas production in covering its own needs increased by $62 \%$ in 2018 .

A sharp $82 \%$ drop in Ukraine's natural gas imports could be observed between 2000 and 2018. Until 2015, most natural gas was imported from Russia, and in recent years the situation has changed - natural gas is imported from EU countries (Slovakia, Hungary and Poland). Import trends have changed, but the natural gas exporter to Ukraine has remained unchanged. Russian natural gas continues to be imported into Ukraine, but now by a longer route, through the countries of the European Union. On the other hand, such a change in the ways of importing natural gas introduces additional guarantees, supported by the European Union, on the stability of Russian natural gas supplies to Ukraine. When analyzing the Ukrainian natural gas sector, it needs to be stressed that this country plays an important role in transiting Russian natural gas to European countries. And although the volume of natural gas transit through the territory of Ukraine between 2000 and 2018 decreased by approximately 20\%, Ukraine still transmits approximately $90 \mathrm{bcm}$ of natural gas to European countries. The agreement between Russia and Ukraine on transiting Russian natural gas to European sectors expires at the end of the year; nevertheless, given the probable lack of alternative routes for the transmission of Russian natural gas to European countries by next year, a new agreement on natural gas transit should be expected, but the implementation of the Blue Stream 2 project in 2020-2021 may reduce the volume of Russian natural gas transit through the territory of Ukraine.

Another advantage of the Ukrainian natural gas sector is the UGS network with its total capacity of approximately $31 \mathrm{bcm}$. This capacity is large enough to be used by other countries.

From a comparison of the structure of natural gas consumption between 2013 and 2018, it results that the largest consumers of natural gas in Ukraine are households.

Work financed by grant AGH No: 16.16.190.779. 


\section{References}

Blue Stream. [Online] https://ru.wikipedia.org/wiki/\%D0\%93\%D0\%BE\%D0\%BB\%D1\%83\% D0\%B1\%D0\%BE\%D0\%B9_\%D0\%BF\%D0\%BE\%D1\%82\%D0\%BE\%D0\%BA [Accessed: 201907-04] (in Russian).

BP 2018. BP Statistical Review of World Energy. June 2018. [Online] https://nangs.org/analytics/download/2530_ae37b3c7c5030b9183745273249d0339 [Accessed: 2018-07-02].

BP 2019. BP Statistical Review of World Energy. June 2019. [Online] https://www.bp.com/content/dam/bp/ business-sites/en/global/corporate/xlsx/energy-economics/statistical-review/bp-stats-review-2019-alldata.xlsx [Accessed: 2018-07].

Gas pipelines bypassing Ukraine. Gas pipelines bypassing Ukraine: active, closed and resuscitated ( $\mathrm{Ga}$ zogony $v$ obxid Ukrainy: aktyvni, zakryti ta reanimovani). [Online] https://tyzhden.ua/News/138798 [Accessed: 2015-06-17] (in Ukrainian).

Gas transit. Gas transit through Ukraine in 2018 decreased by 7\% (Tranzit gaza cherez Ukrainu v 2018 godu sokratilsya na 7\%). [Online] www.unian.net/economics/energetics/10397562-tranzit-gaza-cherez -ukrainu-v-2018-godu-sokratilsya-na-7.html [Accessed: 2019-02-02] (in Russian).

Hydrocarbon exploration. Ukraine will borrow money for hydrocarbon exploration with US companies (Ukraina pożyczy pieniądze na poszukiwanie węglowodorów z firmami z USA. [Online:] https://www. cire.pl/item, 185215,1,0,0,0,0,0, ukraina-pozyczy-pieniadze-na-poszukiwanie-weglowodorow-z-firmami-z-usa.html [Accessed: 2019-08-19] (in Polish).

KALISKI et al. 2015 - KALISKI, M. SIKORA, M.P. and SIKORA, A.P. 2015. Who will fill the Ukrainian gas storage facilities? (Kto napetni ukraińskie magazyny gazu? Polityka Energetyczna - Energy Policy Journal Vol. 18, Iss. 3, pp. 61-74 (in Polish).

KonoŃCZUK, W. 2018. The gas revolution? Prospects for growth in gas production in Ukraine (Gazowa rewolucja? Perspektywy wzrostu wydobycia gazu na Ukrainie). [Online:] https://www.osw.waw.pl/pl/ publikacje/komentarze-osw/2018-09-24/gazowa-rewolucja-perspektywy-wzrostu-wydobycia-gazu-na [Accessed: 2018-09-24] (in Polish).

KARDAŚ et al. 2019 - KARDAŚ, S., ŁOSKOT-STRACHOTA, A. and MATUSZAK, S. 2019. "Last-minute" transit contract? Russian-Ukrainian-EU gas talks (Kontrakt tranzytowy , last-minute”? Rosyjsko-ukraińsko-unijne rozmowy gazowe). [Online:] https://www.osw.waw.pl/pl/publikacje/komentarze-osw/2019-01-25/ kontrakt-tranzytowy-last-minute-rosyjsko-ukrainsko-unijne [Accessed: 2019-01-25] (in Polish).

KwiATKOWICZ, P. and SzCZERBOwSKi, R. 2015. Power industry in times of political instability. Energy security - raw materials and energy market (Energetyka w czasach politycznej niestabilności. Bezpieczeństwo energetyczne - rynek surowców i energii). Poznań (in Polish).

List of population. List of countries in the world by population (Lista państw świata wedlug liczby ludności). [Online:] https://pl.wikipedia.org/wiki/Lista_pa\%C5\%84stw_\%C5\%9Bwiata_wed\%C5\%82ug liczby_ludno\%C5\%9Bci [Accessed: 2019-08-01] (in Polish).

MARTYNENKO, A. 2018. Natural gas production in Ukraine in 2018: on the threshold of change (Vydobutok pryrodnogo gazu v Ukraini u 2018: na porozi zmin). [Online:] https://www.icu.ua/ru/research/blog/ vidobutok-prirodnogo-gazu-v-ukran-u-2018-na-poroz-zmn [Accessed: 2018-05-21] (in Ukrainian).

Naftogaz01. Naftogaz Europe. Natural Gas Consumption and Import in Ukraine, 1991-2018. [Online:] https://naftogaz-europe.com/article/en/naturalgasconsumption andimportinukraine19912018 [Accessed: 2019-01-29].

Naftogaz02. Naftogaz Europe. Gas production in Ukraine, 2015-2018. [Online:]_https://naftogaz-europe. com/article/en/gasproductionin20152018 [Accessed: 2019-01-29].

Naftogaz03. Naftogaz Europe. Gas consumption in Ukraine, 2017-2018. [Online:] https://naftogaz-europe. com/article/en/gasconsumptioninukraine20172018 [Accessed: 2019-01-29].

126 
Naftogaz04. Naftogaz Europe. Gas consumption in Ukraine, 2013-2014. [Online:] http://www.naftogaz -europe.com/article/en/GasConsumptionbcm [Accessed: 2015-02-02].

Naftogaz05. Naftogaz Europe. Natural Gas Transit via Ukraine, 1991-2017. [Online:] http://www.naftogaz-europe.com/article/en/naturalgastransitviaukraine2017 [Accessed: 2018-02-12].

Naftogaz06. Naftogaz Europe. Natural Gas Consumption and Import in Ukraine, 1991-2018. [Online:] https://www.naftogaz-europe.com/article/en/naturalgasconsumptionandimportinukraine19912018eng [Accessed: 2019-01-30].

Naftogaz07. Naftogaz Europe. Natural Gas Supplies to Ukraine 2008-2016. [Online:] https://www.naftogaz-europe.com/article/en/NaturalGasSuppliestoUkraine [Accessed: 2017-01-10].

Naftogaz08. Naftogaz Europe. Gas imports to Ukraine 2017-2018. [Online:] https://naftogaz-europe.com/ article/en/gasimportstoukraine20172018 [Accessed: 2019-01-29].

Nord Stream. Nord Stream Secure gas supply for Europe. The Pipeline. [Online:] https://www.nord-stream. com/the-project/pipeline/ [Accessed: 2019-01-29].

Permission List 2015. List of special permissions for subsoil use. Date of issue of the document 18/05/2015 (Perelik speczialnyx dozvoliv na korystuvannya nadramy. Data vydachi dokumenta 18/05/2015 roku). [Online:] https://menr.gov.ua/files/docs/VUG_SLANC_SAPR_TORF1.pdf [Accessed: 2015-05-18] (in Ukrainian).

Russian gas pipeline. Gas pipeline (Gazociag). [Online:] https://pl.wikipedia.org/wiki/Gazoci\%C4\%85g\#/ media/File:Major_russian_gas_pipelines_to_europe.png [Accessed: 2018-01-16] (in Polish).

RUSZEL, M. 2014. Diversification of natural gas supply directions to Ukraine - a political objective or a negotiating instrument? [In:] Energy security. Raw materials and energy markets - present and future. Volume 1 - Politics - Economy - Natural Resources and Logistics (Dywersyfikacja kierunków dostaw gazu ziemnego na Ukraine - cel polityczny czy instrument negocjacyjny? [W:] Bezpieczeństwo energetyczne. Rynki surowców i energii - teraźniejszość i przyszłość. Tom 1-polityka-gospodarka-zasoby naturalne i logistyka), P. Kwiatkowski, Poznań, pp. 75-102 (in Polish).

Transit revenues. Revenues of Ukraine from gas transit exceeded expenses on its import (Doxody Ukrainy ot tranzita gaza prevysili rasxody na yego import). [Online:] https://ru.espreso.tv/news/2019/01/23/ dokhody_ukrayny_ot_tranzyta_gaza_prevysyly_raskhody_na_ego_ymport [Accessed: 2019-01-23] (in Russian).

Ukrtransgaz. Naftogaz. Ukrtransgaz. Characteristics of the gas transportation system of Ukraine (Xarakterystyka gazotransportnoyi systemy Ukrainy). [Online:] http://utg.ua/utg/gts/description/ [Accessed: 2019-04-16] (in Ukrainian). 


\title{
Sektor gazu ziemnego w Ukrainie - szanse i bariery rozwoju
}

\begin{abstract}
Streszczenie
W artykule przeprowadzono analizę sektora gazu ziemnego na Ukrainie w latach 2000-2018. Na sektor ten oddziaływały czynniki zewnętrzne, takie jak kryzys finansowy, który rozpoczął się na przełomie 2008/2009, a także czynniki wewnętrzne, w tym sytuacja na Ukrainie po 2013 r. (aneksja Krymu). Również przeprowadzono analizę porównawczą sektora gazu ziemnego krajów Unii Europejskiej oraz Ukrainy porównano, jak kształtowało się jednostkowe zużycie gazu ziemnego w $2018 \mathrm{r}$. Przeanalizowano zapotrzebowanie na gaz ziemny na Ukrainie w latach 2000-2018 oraz scharakteryzowano zmiany w zakresie źródeł pokrycia popytu na gaz ziemny, ze szczególnym uwzględnieniem wydobycia własnego, a także wskazano na zasadnicze zmiany, jakie zaszły $\mathrm{w}$ ciągu ostatnich lat w kierunkach dostaw gazu ziemnego z importu na ukraiński rynek. W odróżnieniu od państw UE, podkreślono rosnącą rolę wydobycia własnego w zbilansowaniu potrzeb gazowych Ukrainy, co jest zbieżne ze strategią rządu ukraińskiego. Scharakteryzowano rolę Ukrainy jako kraju, przez którego terytorium realizowany jest tranzyt rosyjskiego gazu do krajów UE (w ciągu ostatnich lat wolumen przesyłanego gazu ziemnego ukraińskiego systemu przesyłowego kształ-

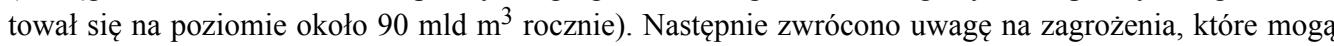
w istotny sposób wpłynąć na ograniczenie roli Ukrainy jako istotnego państwa tranzytowego. Porównano także, jak zmieniła się struktura zużycia gazu ziemnego na ukraińskim rynku gazu w ciągu ostatnich lat. W artykule również przybliżono najważniejsze parametry bazy PMG w Ukrainie, jednej z największej w Europie.
\end{abstract}

SŁOWA KLUCZOWE: bezpieczeństwo energetyczne, polityka energetyczna, gaz ziemny, sektor gazu ziemnego 